\title{
クロム コラーゲン織維の製造とその利用
}

\section{1.はじめに}

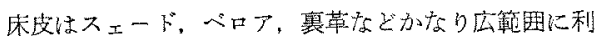
用されているが，皮は部位によりコラーゲンの太さ，織

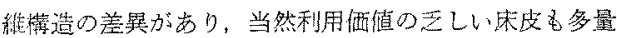

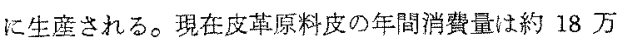
トンに達し，末利用の枺皮はその䄪 $30 \%$ にるので，

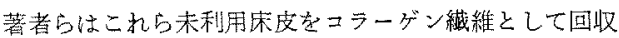
利用する方法の開発の研究を谁好た。

皮からコシーゲン瀻維を回収する方法としては，つぎ ○3つK大別される。すな和尚，(1)化学的処理により コラーダンを溶液の状態で抽出し，異なる条件下で䌜維 として再生する方法，たと党ば日本皮革株式会社のトり プシン処理によるコラーゲン瀻維再生に関する特許1), (2)化学的処理を行なってコラーゲンのミセル皘造をあ 当程度破填したのち物理的手段によりチップ状に，㐫る いはスラリー状化し，こ和を異なる条件下でシート状化 固定する方法，たと视アーマア社のとドラジンによる コラーダンの再生に関する特許2)，(3) 物理的手段で数

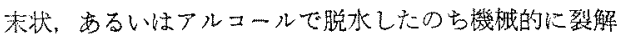
するカール，フッイデンベルグの特許引゙な゙である。し かし，良来試及られなかった皮革織物，吉大現在登展途 上にある合成皮革の基布である不鐡布の原料として啇用 し5るコラーゲン織維を，経済的要装を念わた点で工業 化されたとの報告は見あたらない。

床皮をえるためのスプリット作業は，膨潤した石灭裸

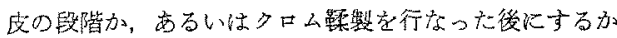
生産の合理化のため多〈の閐惪含含九でいる。一般厄脱 毛・石灰漬後の裸皮のスプリット作業は床の利用轁用が

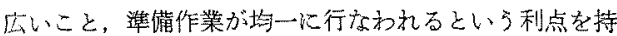
っているが，アルカリ膨閏をしている裸皮をスプリット

The Preparation and Utilization of Chromed Collagen Fiber

* HIROSHI OKAMURA, Yamazaki Chemical Laboratory Ltd., Soka-City, Saitama Pref., Japan., 株式会社山㱦化学研究所技術士(化学)

** AKIRA MAWATARI, Tohko Textile Engineering Consultants Ins., Kanda, Tokyo, Japan 東弘㵶維技術研筑听 技術士(瀻維)
䦦村 浩* 一黑渡 明**

するには，技術的に困難があり，眝間と手間がかがり， 膨潤による愿度と仕上後の製品磨度の差が大きいため， シェービング作業など比较的長時間が必要となる。した

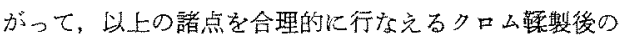

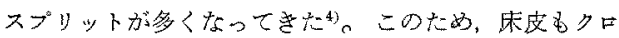
么㦿革として集荷される量が藷しく多く，またコラーゲ ンの欠点と考无られている熱収綃性も，ワ口ム処理のた

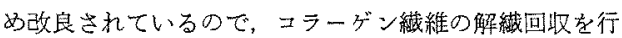
なら材料として最適で劣ると栲文られた。

著者らは，原料的に豊富々考无られるクロム床革を解 䋐しクロム コラーゲン瀻維を回収する方法を検討して きたが，現在工業化の段階にすで澾したので，こ机らの 開発経過およびその利用面につきとりをとめる。

\section{2. クロム床革からクロム・コラーゲン 繊維の回收 ${ }^{5,6}$}

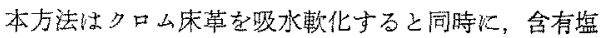
類呿よび水溶性物質を除去し，これにアルカリょよび尿

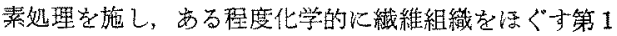
工程と，上記処理物を硫酸化エマルジョンで加脂を行な ったのら脱水半乾橾する第 2 工程と，この半乾燥爸理物 を肺解する第 3 工程と，さらにこの処理物を強力な特殊

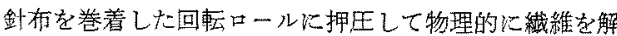
絨する第 4 工程とを結合した一連の工程で，クロム床革 よりクロムコラーゲン緎維を解繊回収するものであ る。

第1工程に持いては，非イオン佸性剂を含えだ 50〜 $60^{\circ} \mathrm{C}$ の温水中に浸瀘し十分吸水を行なった後，30〜60 分間必要に応じて空ドラム中で回転し軟化する。軟化 たクロム床草は再び温水中に漫漬し含有されている塩化 ナトリウム，硫酸ナトリウムそのたの水溶性物質を除去 t)。

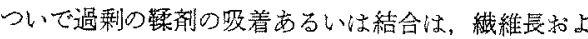
び感触を損なうので，コラーゲンの熱収縮を $90^{\circ} \mathrm{C}$ 以上

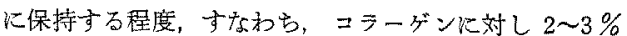
の酸化クロム $\left(\mathrm{Cr}_{2} \mathrm{O}_{3}\right)$ k脱タロム处理を施して謂整す

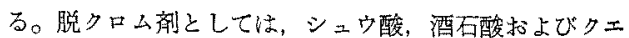
ン酸などの多塩基酸の悕薄溶洨を使用する。。たと总ば 
クロム床革の $250 \%$ 量温水 $\left(40 \sim 50{ }^{\circ} \mathrm{C}\right), 0.1 \sim 1.0 \%$ 量 シニウ酸とともに 30 分〜1時間ドラム中で回転すれば よい。脱ク口ム処理を終了したクロム休䩶は水洗し，菏 性ソーダ，炭酸ソーダ，重破酸ソーダなどのアルカリ睎 薄溶液に浸清し中和処理を行な5。この埸合、熱收綰温 度の低下，コラーダンの膨潤度，硫酸酸度などから检討 した結果，重炭酸ソーダ程度のアルカリ強度が最站で岕 る。浸清処理策件は， 刀口ム床革の $\mathrm{pH}$ が 5.2 6.4 程 度，穊别にはいわゆる均一中和を行なら。

以上の処理を行なったクロム床革は，常温を0.1\%圂 素溶液により浸清好理を行なう。この処理に上って䌭維 末のから正合いが緩められ細くかつ長くかき取ることが


が主因と考えられ，組織のあまり密でない部分では，こ ○姏理を省略することがでさる。

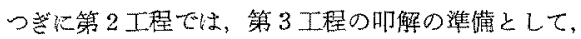
原料の重量に対しI\%程度の硫酸化油エ、ルジョン加脂 を行なったのb，艺の水分会有星が 35〜 $50 \%$ になる字 で脱水就燥する。この加脂は䋐維束が吒解に上り極踹に 短かくなることを斯くため重要な工程であり，添加する

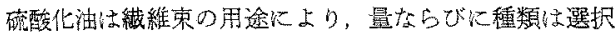
しなければならない。一般的なるのは，牛脚油，オリー ブ油の此較的硫酸化度が高いるのである。水分含量の

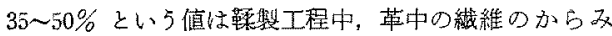

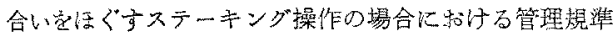
ですり朾解か円滑に行なかれる。

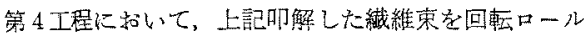
に䍗着した强力な針布に押王することにより容㞣に所期

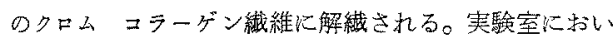
ては, 針の長さ $4 \mathrm{~mm}, 1 \mathrm{~cm}^{2} に 3$ 本を植え込んたもの を針布として使用した。

クロム床革は部位により維維の交絡の強さに差暴があ

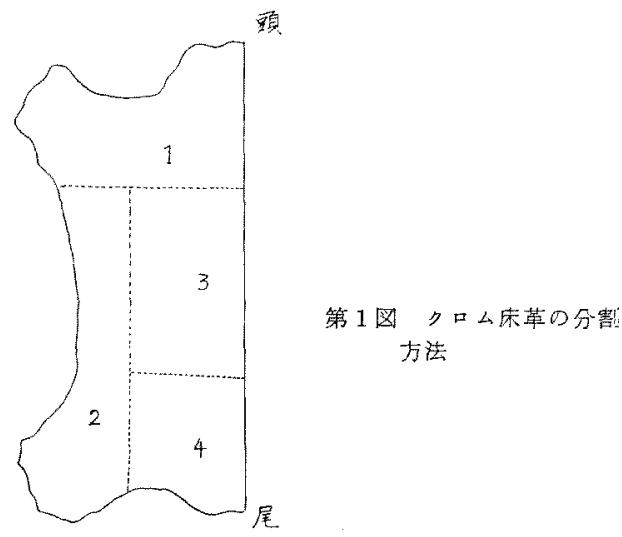

第 1 表 部位による解瀻処理時間，短㵶雜含有萃，革小

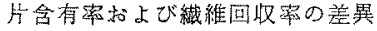

\begin{tabular}{|c|c|c|c|c|}
\hline \multirow{2}{*}{ 測定項目 } & \multicolumn{2}{|c|}{ 部 } & \multicolumn{2}{|c|}{ 位 } \\
\hline & 1 & 2 & 3 & 4 \\
\hline 解繊処理眭間（分） & 45 & 40 & 110 & 120 \\
\hline 短緎維含有蜜 $(\%)$ & 15.2 & 20.4 & 56.3 & 58.1 \\
\hline 革小片含省率 $(\%)$ & 7.8 & 10.3 & 1.4 & 2.3 \\
\hline 織踓回収帚 $(\%)$ & 77.0 & 69.3 & 42.3 & 29.6 \\
\hline
\end{tabular}

り，これが解繊回收に大きく影響する。クロム床革を原 料として，上記の方法により乾燥工程まで行なった。乾

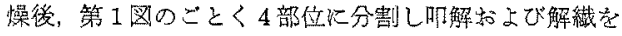
行なった。すなわ方，各部位別に解瀻処理を行ない，処 理物 $1 \mathrm{~kg}$ を负る以要する時開を解瀻処理時間，また 1 $\mathrm{cm}$ 以下の繊維篩別し，この重量を求め処理物全重量

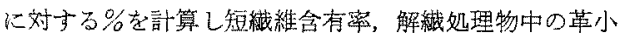
片も前同栓に訢算し革小片含有率として比慗した。した がって，㵶維回収率は 100-（短䋐維含有率十革小片含 有密）として求められる。この結果は第1表のごとくて b。

以上の結果より，解緎時間，短瀻維含有率，革小片含

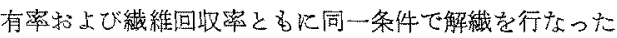
場合に有意差が認められる。解䋘時間は部位 $2 か ゙ 40$ 分 で一番解瀻が容易である。これに反し，部位 3 扣よび 4 はそれぞれ 110 分，120分となり約 3 倍の時間索解瀻心 要す。革小片含省率は，部位 2 が $10.3 \%$ で番多々， 部位了放さび4はそれそれ $1.4 \% ， 2.3 \%$ で非常に少な い。この結果は部位 2 の組絨構造が他の部位儿比較しル ーズなため瀻維に解瀻される場合に小片に切断されるる

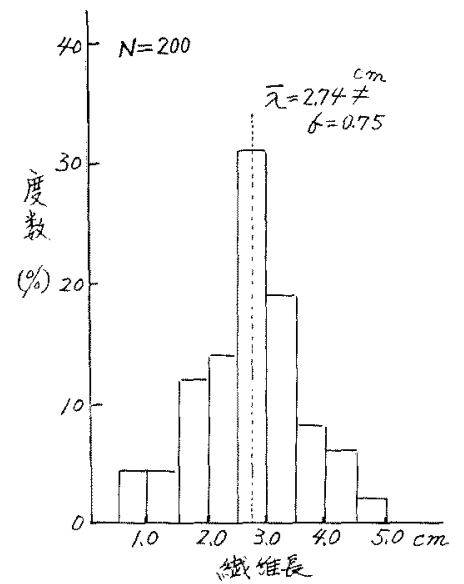

第 2 図 解䇅观理によりえられたクロム・ニ

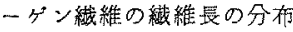




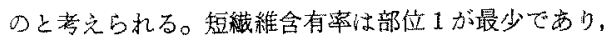
15.2\%，部位3括よび 4 が $56.3 \% ， 58.1 \%$ であり，解 䋐された大半が $1 \mathrm{~cm}$ 以下の短瀻維であること示して

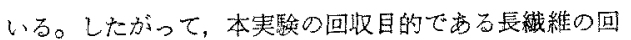

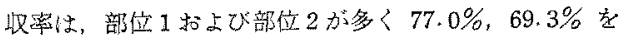
示している。これらの結果は，革中のコラーダン絾維構

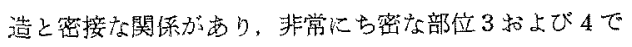

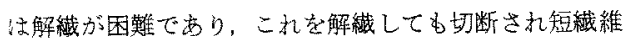
となる。組織構造の粗な部位 1 文よび部位 2 では, 比較

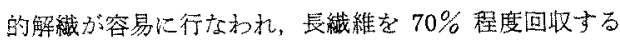
ことがでさるしたがって，クロム コラーダン紻維の 回収に使用する原料は，部位1(ショルダー）蛒よび部

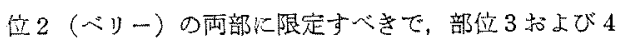
は従来の床スェード、ベロアの製造原料とすることが経 済的にも好ましい。

\section{3. クロムーコラーゲン緎維の性樷}

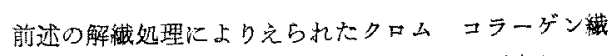
維中から200本を任意に抽出し，その長さを測定しヒス トグラム画いた。結果は第 2 图のごとくであり，2.5 $\sim 2.9 \mathrm{~cm}$ の長さを有するものが一番多く約 $30 \%$ を占め 平均長は $2.74 \mathrm{~cm}$ であった。この分布は正規分布索示 し，ク口ム床勒乩られる䋐維俚大体 $2.7 \mathrm{~cm}$ 程度の bのと考克られた。この第合， $1.5 \mathrm{~cm}$ 以下，2.5 2.9 $\mathrm{cm}$ 扣よび $4.0 \mathrm{~cm}$ 以上のクロム ヨラーダン絾維を集 めク口ム含有量を測定したところ， $1.5 \mathrm{~cm}$ 以下： 3.42 $\%, 2.5 \sim 2.9 \mathrm{~cm}: 2.80 \%, 4.0 \mathrm{~cm}$ 以上: $2.32 \%$ (い) れ皮質分飞対する $\mathrm{Cr}_{2} \mathrm{O}_{3} \%$ として示す）であり瀻維 長にクロム含有量が影䍌することを知った。

クロムコラーゲン繊維の重さを $1 \mathrm{~cm}$ 当りに刘方る

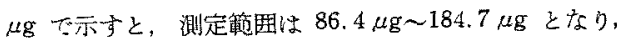

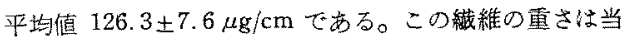
然ク口ム含有量含脂量なぐにより变動があるものと考之 它少。

$3 \cdot 2$ クロム・コラーゲン䋞維の機械的性筫

クロムコラーダン゙㵶維の機械的性 質々して切断時の荷重と伸びを測定し た。タロム・コラーダン縅維の切断時 の荷重 $(\mu \mathrm{g} / \mathrm{cm})$ 特よび伸びと緎維 の重さ执よびクロム含有量の差異によ る变動を第 3 図と第 4 図に示した。す なっち，切断時の荷重は瀻維の重さ $(\mu \mathrm{g} / \mathrm{cm})$ 和よびクロム含有量が增加す るにしたがい减少する。しかし，切断 の伸びには明蹽な関係を見出せなかっ た。前述の標準的なクロムコラーゲ ン繧維 $(126.3 \mu \mathrm{g} / \mathrm{cm})$ の切断時の荷 重は $114.0 \pm 5.4 \mathrm{~g}$ ，伸びは $19.2 \pm 1.4$

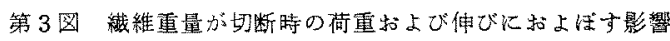

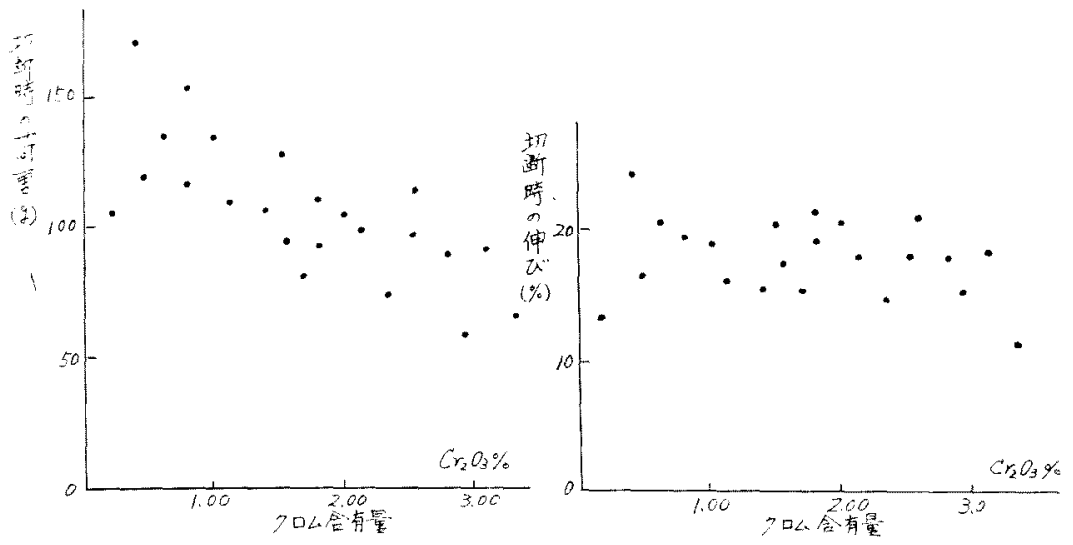

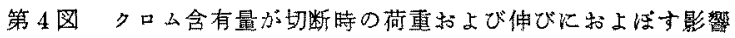


第 2 表 工業的規模で回収されたクロムエララーダン䋐維の組成

\begin{tabular}{|c|c|c|c|c|c|c|c|c|c|c|c|c|c|c|c|}
\hline 測定 & 1 & 2 & 3 & 4 & 5 & 6 & 7 & 8 & 9 & 10 & 11 & 12 & 13 & 14 & 5 \\
\hline 分 & & 8 & 2 & & 2 & & & & & & & & & & 7 \\
\hline 分 & 6.58 & 8.24 & 7.94 & 7.28 & 7.11 & 6.89 & 7 & 6 & 7.11 & 6.49 & 7 & 6.49 & 6.52 & 7.20 & .8 \\
\hline 厶 & 5. & 3.72 & 3.82 & 3.41 & 4 & 3.72 & 3 & 3.47 & 2 & .92 & 2 & t & 5.54 & 6.41 & \\
\hline$=7$ & 3.90 & 74.79 & 74.62 & 74.27 & 73.89 & 74.89 & 74.09 & 74.59 & 74.89 & 74.36 & 74.14 & 74.38 & 74.60 & 74.50 & 75. \\
\hline $\mathrm{pH}$ & 4.71 & 5.20 & 5.39 & 6.10 & 5.11 & 5.32 & 5. 36 & 5.01. & 6. 12 & 4.11 & 4.37 & 4.26 & 4. 37 & 4.09 & 3.7 \\
\hline
\end{tabular}

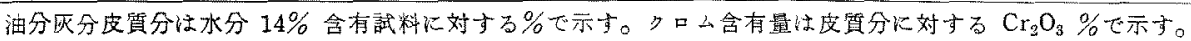

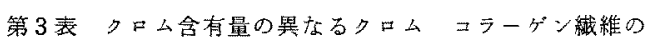
熱收縮温度と皮質分の損失

\begin{tabular}{|c|c|c|c|c|c|c|c|c|}
\hline \multirow{2}{*}{ 測 定項目 } & \multicolumn{8}{|c|}{ 皮䁈分に対をるクロム含有量 $\left(\mathrm{Cr}_{2} \mathrm{O}_{3} \%\right)$} \\
\hline & 0.50 & 0.75 & 1.02 & 1.54 & 1.72 & 2.10 & 2.89 & 4.23 \\
\hline 熱权縮温度 ${ }^{\circ} \mathrm{C}$ & 78 & 81 & 85 & 90 & 94 & 96 & $100 *$ & $100^{*}$ \\
\hline 皮質分の損失\% & 10.27 & 8. 59 & 2.99 & 0.85 & 0.35 & 0.20 & 0.10 & 0.04 \\
\hline
\end{tabular}

第 4 表 クロム ニラーダン䋐維の湿熱取縮率の温度による变化

\begin{tabular}{cc|c|c|c|c|c|c}
\hline 㵋清温度 & ${ }^{\circ} \mathrm{C}$ & 75 & 80 & 85 & 90 & 95 & 100 \\
\hline 収緬率 & $\%$ & 0.0 & 4.2 & 30.2 & 32.8 & 35.7 & 42.7
\end{tabular}

$\mathrm{Cr}_{2} \mathrm{O}_{3}$ として2.0\%以下のクロム コラーゲン瀻維使用 浸渍時間：3分間

(A)
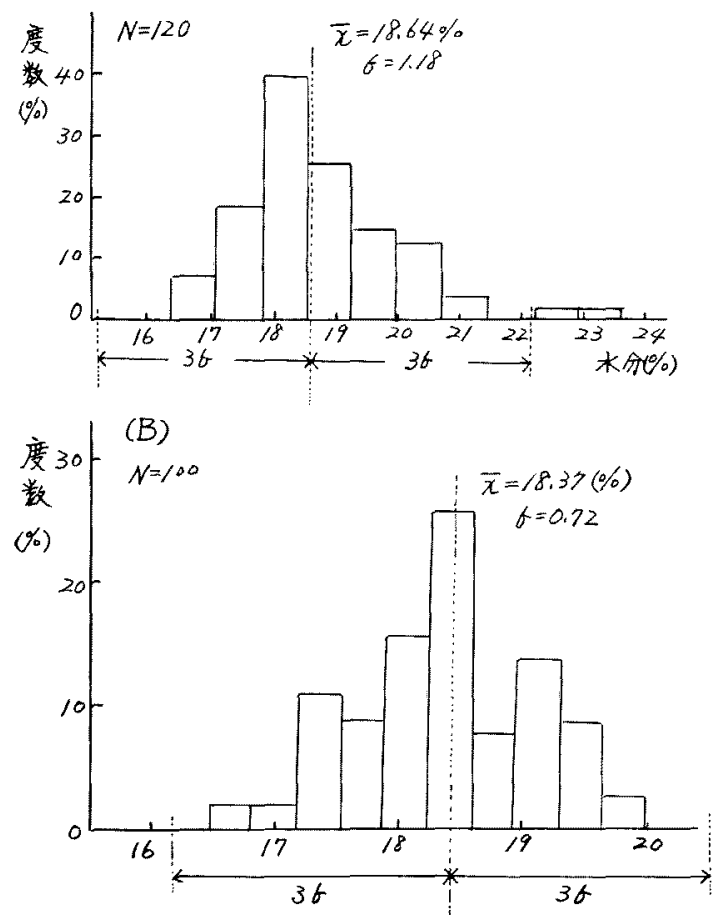

第5図クコム・ニラーダン維維の平衡水分含有量の分布

星度である。

$3 \cdot 3$ クロム・コラーゲン䋊維の平衡水 分量

$20^{\circ} \mathrm{C} ， 65 \%$ RHに和けるクロム コラー

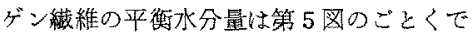
ある。Aはクロム含脂量の異なる100ロッ ト上り計算され、Bはクロム含有量 $3 \%$ 前 後 $\left(\mathrm{Cr}_{2} \mathrm{O}_{3}\right.$ として $)$ の含脂量同一のものを 選び計算したものである。この結果から平 衡水分量はタロムおよび含脂量により多少 変化するも $18 \%$ 程度と考光られる。

工業的な規模でクロム床革より回収せら れたクロム・コラーゲン䌜維（使用目的の 関倸上，脱躁処理を行なっていない）の分 析值は第 2 表のごとくで, 各測定檤の範因 洂, 含脂量: $1.41 \sim 3.09 \%$, 㚒分: 6. 49 $8.24 \%$ ，クロム含有量: $4.02 \sim 6.41 \%$, 皮 賀分：73. 89 75.11\%， $\mathrm{pH}: 3.72 \sim 6.12$ \%であった。この測定値の変動は原料です らクロム床革の性状が大をく影缽するる。 と考党られる7。

タロムコラーダン紻維は吸水し多少膨 潤するが，浸漬液の $\mathrm{pH}$ に上り第 6 图のご 上く変化する。 $\mathrm{pH} 3$ 以下执よび $\mathrm{pH} 10$ 以 上ではそそれぞれ酸膨潤就よ゙アルカリ膨 潤を生ずる。 pH 3〜8の籍团では pH の影 響は認められない。

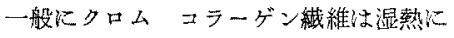
より熱收縮を起こさないが，コラーダン瀻 維の皮貿分に対するクロム吸着量が少ない 々熱収縮の現象が認められ, 改修処理を行 なっていないコラーゲン繊維では $60^{\circ} \mathrm{C} て ゙$ $2 / 3$ 程膺の熱収縮を生ずると共にゼラチン 化が起こる。コラーゲン緎維のクロム含有

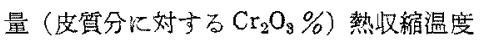
および皮質皮質分の損失量の関係を示すと 第 3 表のごとくである。ただ第 3 表の数 


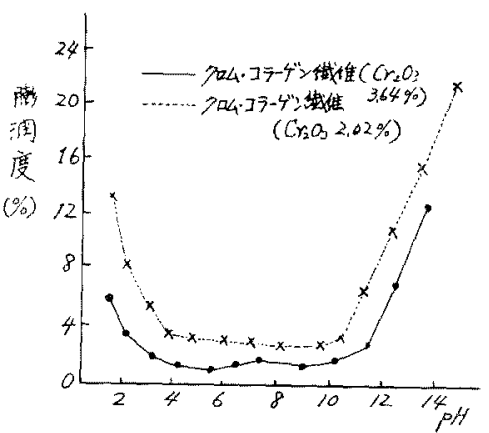

第6図 pHによるクロム ニラーケ゚ン維維の膨潤

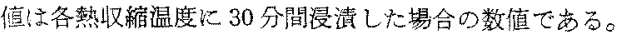
$\mathrm{Cr}_{2} \mathrm{O}_{3}$ として1\%吸着しているタロムコターゲン鐵維! の浸婊温度と収紑察の变化の関係第 4 表のごとくであ るここの上うにクロムコラーダン瀻維のクロム含有量

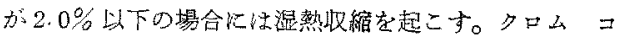

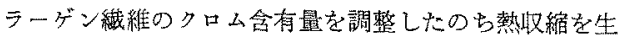
せしめフェルト化に利用することがでさる。

クロム・コラーゲン笺維は酸あるいは塩の溶液に浸漬 するときには，その酸拈よび程の酸根が下記の順列の硫

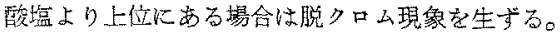

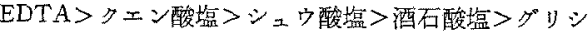
ン>乳酸塩, チオシアン酸程〉酰酸塩〉硫酸塩〉程酸塩 第 5 表はこの脱クロム現象の1例を示与すので, この上 うな脱クロム現像は，クロムと脱クロム現象を生ずる酸 櫸との配位化合物形成能力の強弱，ならびに生成される クトム錯塩のコラーダンに対する親和性の差罢にもとつ

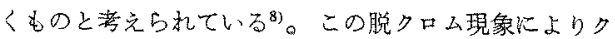

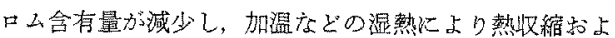
びゼラチン化が 2 次变化をして㒛められる。したがって, オキシ多塩基酸するいは央の塩の水溶液での浸清処理に

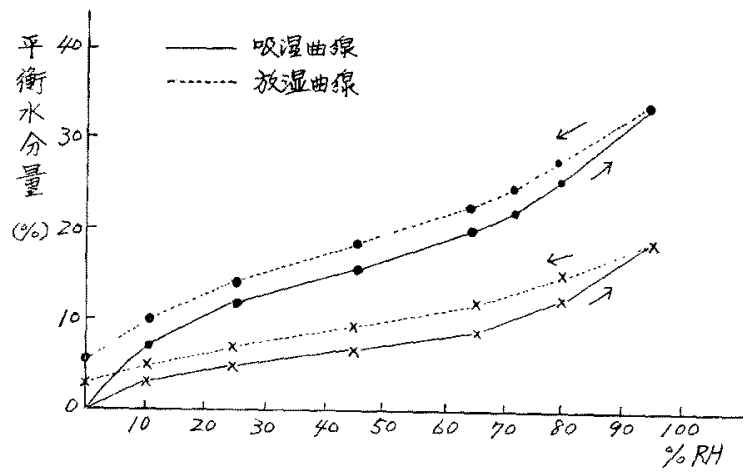

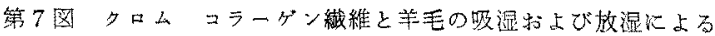
平衡水分含有舅の变化
第5表クロム ヌラーグン緎維の脱ク口ム現象

\begin{tabular}{|c|c|c|c|c|}
\hline \multirow{2}{*}{ 溲 清 溶 液 } & \multicolumn{4}{|c|}{ 浸漬処理時間（hrs） } \\
\hline & 1 & 2 & 3 & 4 \\
\hline 壏化ナトリウム & 0.03 & 0.05 & 0.14 & 0.28 \\
\hline 硫酸ナトリウム & 0.38 & 0.41 & 0.69 & 2.76 \\
\hline 酥酸ナトリウム & 0.41 & 2.21 & 4.14 & 8.8 \\
\hline 乳酸さトリウム & 2.19 & 3.41 & 6.72 & 11.59 \\
\hline シニウ酸ナトリウム & 4.59 & 8. 09 & 14.57 & 21.41 \\
\hline 酒石酸ナトリウム & 3.29 & 5.42 & 10.11 & 16.71 \\
\hline クエン酸ナトリウム & 6.72 & 8.89 & 15.98 & $23 \cdot 36$ \\
\hline
\end{tabular}

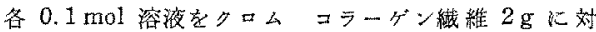
ᄂ $100 \mathrm{ml}$ 使用 (液温 $25^{\circ} \mathrm{C}$ )

第6 表クロム コラーダン維維のウェッブ形成性

\begin{tabular}{|c|c|c|c|c|c|}
\hline \multirow{2}{*}{ 混用㵶 維 } & \multicolumn{3}{|c|}{ 湦用量 (需量\%) } & & \multirow{2}{*}{ 䓔 } \\
\hline & 40 & 20 & 10 & & \\
\hline \begin{aligned} & テ \multicolumn{2}{c}{$6 \mathrm{~d}$} \\
& 長さ $3.2 \mathrm{~cm}\end{aligned}$ & 良 & $p$ 而 & 不可 & $18^{\circ} \mathrm{C}$ & $63 \% \mathrm{RH}$ \\
\hline 長さ $3.5 \mathrm{~cm}$ & 良 & や队良 & p户可 & $18.5^{\circ} \mathrm{C}$ & $64 \% \mathrm{RH}$ \\
\hline スフ長さ $5.0 \mathrm{~cm}$ & 良 & 良 & 不可 & & - \\
\hline
\end{tabular}

良・良好なウェップに成形される就会 やや良・多少ウエッブがくずれる場合

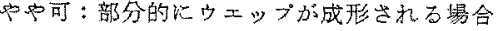
不可：ウェップに成形が不可能の場合

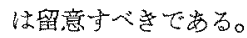

クロム・コラーゲン瀻維 Orange II K対する染着性 は $\mathrm{Cr}_{2} \mathrm{O}_{3}$ として $3.42 \%$ を含を $1.5 \mathrm{~cm}$ 以下の織維が， $2.5 \sim 2.9 \mathrm{~cm}$ 招よび $4.0 \mathrm{~cm}$ の緎維 $\left(\mathrm{Cr}_{2} \mathrm{O}_{3}\right.$ として 2.80 \%扎上び2.32\%)上りる良好であった。これはクロム 含有量による塩基性基の活性化に上るものと考它られ， $\mathrm{Cr}_{2} \mathrm{O}_{3}$ とて $4 \%$ 程度が染着率が最も好良で㐬る゙。

4. クロム・コラーゲン繊維の利用

$4 \cdot 1$ クロム コラーゲン織維の吸湿放湿 性の利用(0)

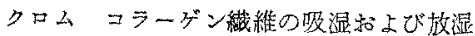

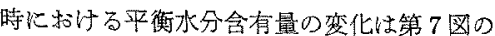
こ゚とくである。すなわら，同一相対湿篖に尔

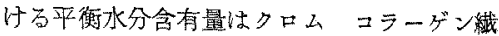
維が多く，平衡に達劣る時間夺羊毛に比較し， て蕏しく速かった。したがって，ク口ム床革 より解蟣せられたクロムコラーダン瀻維が 良好な吸放混性在羊すことは，新しい利用方 法として注目す心゙ことと考党られる。 つぎに舆さ2〜3cmのタロム・シーダン 
瀻維のウェップ成形性の桱討の結果は第 6 素のごとく で，単独では满足なウェッブを成形することはできない、 が、クロム ニラーダン緎維から長い他の瀻維を $40 \%$ （重量）程度混用することにより，良好なウエップとな 第て表 カイロンとクロム ニラーゲン織維混角ウ エップの吸湿度の比䔒

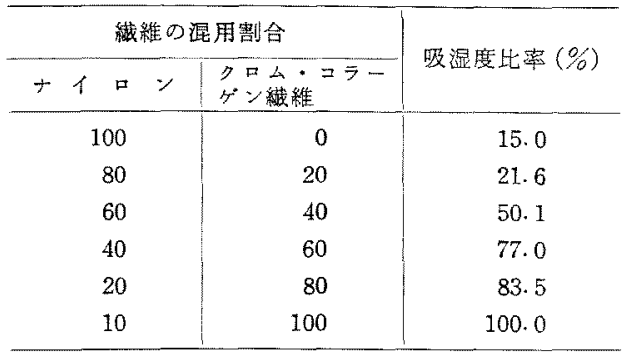

第8表 木綿とクロム ニラーゲン織維混用ゥエッ $フ ゚ の$ 吸湿度の比較

\begin{tabular}{|c|c|c|c|}
\hline \multicolumn{3}{|c|}{ 䋐維の混用割合 } & \multirow{2}{*}{ 吸湿度此率 $(\%)$} \\
\hline$\pi$ & 綿 & 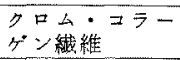 & \\
\hline & & 0 & 65.6 \\
\hline & & 20 & 68.7 \\
\hline & & 40 & 78.8 \\
\hline & & 60 & 88.2 \\
\hline & & 80 & 91.6 \\
\hline & & 100 & 100.0 \\
\hline
\end{tabular}

第9麦 グム コラーダン緎維と他の各種緎維の 混用によるフェルトの機械的性筫

\begin{tabular}{|c|c|c|}
\hline 泳用蟣維 & 強力 $\left(\mathrm{g} / \mathrm{cm}^{2}\right)$ & 伸度 $(\%)$ \\
\hline 綿 & $293 \sim 338$ & $50 \sim 56$ \\
\hline 筷りニステル & $381 \sim 426$ & $52 \sim 69$ \\
\hline$v-\equiv y$ & $220 \sim 275$ & $27 \sim 36$ \\
\hline$\equiv$ & $189 \sim 241$ & $25 \sim 38$ \\
\hline
\end{tabular}

第 10 表 クロム・コラーダン緎維による不緎布の物理的 性揗の比皎

\begin{tabular}{|c|c|c|c|c|c|c|c|}
\hline 測 定 项 & 項 目 & $\begin{array}{l}\text { ポリエ } \\
\text { スデル }\end{array}$ & $=10$ & $\begin{array}{l}v-\exists \\
y\end{array}$ & 羊毛 & 木綿 & $\begin{array}{l}E^{*}=m \\
y\end{array}$ \\
\hline ウニップ目付 & $\left(\mathrm{g} / \mathrm{m}^{2}\right)$ & 480 & 475 & 490 & 500 & 510 & 460 \\
\hline 繁品目付 & $\left(\mathrm{g} / \mathrm{m}^{2}\right)$ & 710 & 720 & 715 & 730 & 740 & 716 \\
\hline 筝 & $(\mathrm{mm})$ & 1.24 & 4. 1.26 & 5. 1.22 & 1.36 & $6 \quad 1.40$ & 1.22 \\
\hline 見か十口比重 & $\left(\mathrm{g} / \mathrm{cm}^{3}\right)$ & 0.42 & 0.40 & 0.44 & 10.48 & $\begin{array}{ll}8 & 0.51\end{array}$ & 0.42 \\
\hline 抗 强 & $\left(\mathrm{kg} / \mathrm{mm}^{2}\right)$ & 0.51 & 0.42 & 0.38 & $\begin{array}{l}3 \\
0.27\end{array}$ & $7 \quad 0.49$ & $9 \quad 0.39$ \\
\hline 引到強度 & $(\mathrm{kg} / \mathrm{cm})$ & 12.4 & 8.9 & 9.2 & $7 \cdot 6$ & 10.2 & 8.2 \\
\hline び & $(\%)$ & 49 & 46 & 32 & 30 & 44 & 40 \\
\hline 破裂強度 & $\left(\mathrm{kg} / \mathrm{cm}^{2}\right)$ & 13.4 & 10.9 & 9.2 & 7.6 & 11.5 & 10.3 \\
\hline
\end{tabular}

ることが認められた。

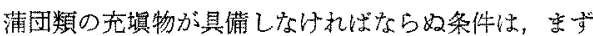
充填可能な形成性を古与，この成形物が弾力性，屈撓性

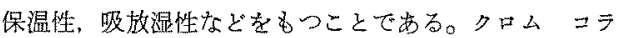
ーゲン緎維は第 7 図に示されたごとく，夏好な吸放埧性 之第 6 㸚の結果より他種綪維との混用に上り形成性は冠 好々なるので，蒲団充增物の材料として最適なものと考 定られる。ナイロン和よび本綿との混合物に和いて第 7 表、第8表のごとき吸湿度比萫が克られた。ナイロン 40 \%混合の場合はナイロン単独の場合上り約 5 倍, 木綿 40 \%の暘合でも20\%の吸湿性が改良さ机ている。

\section{$4 \cdot 2$ クロム・コラーゲン䋞維の熱収縮性を利用した フェルトの製造行}

$3 \cdot 3$ で記載したごとく，一般にクロム・コラーゲン織 維は湿熱により熱収綟を起こさないが，ク口ム含有睤が 2.0\%以下の場合には温水中で浸漬する上熱收縮を生す

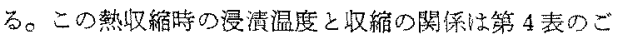

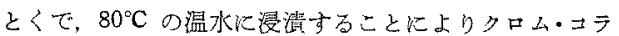

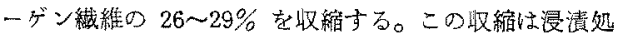
理 5 分間壁度で乎衡に達する。この湿熱取縮を利用して フェルト化の処理が可能である。クロム コラーゲン䋘 維に木線、テトロン, スフ, 羊毛を $40 \%$ (重量) 混用し

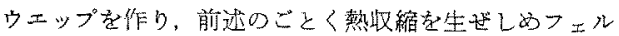
下化処理䘮施した。このフェルトの物理的性筫の测定值 は第 9 表のごとくである。平均値は棉：强力 $313 \mathrm{~g} /$ $\mathrm{cm}^{2}$, 仰度 $53 \%$ ，テトロン: 強力 $398 \mathrm{~g} / \mathrm{cm}^{2}$, 伸度 65 $\%$, スフ: 強力 $247 \mathrm{~g} / \mathrm{cm}^{2}$, 伸度 $33 \%$, 羊毛: 强力 227 $\mathrm{g} / \mathrm{cm}^{2}$ ，体度 $32 \%$ となり，テトロン混用のフェルトが

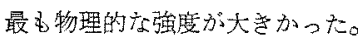

4 .3 クロム・コラーゲン瀻維による不織布の製造12,13) クロム・コラーゲン瀻維は不織布に製造できる。特に 合成皮荤の基有用としては，吸収湿性のナぐれている特 性のため最適のものと考えられる。

クロム・コラーゲン瀻維にポリエステル、ナイロン， レーシン，羊毛，木綿，ビニロンをオープナー お゙よびブレンダーを使用して 40\% 量混入し， カードに通過させウェップを形成後, ニードル

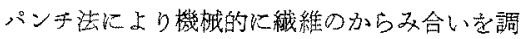
整した。ニードルは $1 \mathrm{~cm}^{2}$ 当り䄪 200 本とし，

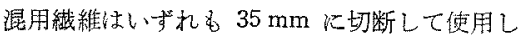
た。パインダーとしては非反沈型アタリル酸エ チルを使用した。このバインダーはノニオン型 乳化剂で重合した重合度約 2000 のホリアクリ ル酸エ、ルジっンである。バインダー濃度走 40\%にあらかじめ希䣋しこの中にトリ人キ キールメラミン樹脂を少蹱ずつかくはんしなが 
ら添加して，螌媒として有幾アミン塩を加克，水で全体 の濃度を $25 \%$ に希釈して使用した。不織布は前述のウ エップを含浸法で作成した。

以上に上り謂整された不織有の物理的性質は第 10 表 のごとくである。混入される䋞維の種類により，不織布 の物理的性質は異なり，ポリステル混用の場合は、抗張 力: $0.51 \mathrm{~kg} / \mathrm{mm}^{2}$, 伸び : $49 \%$ ，引裂強度 : $12.4 \mathrm{~kg} / \mathrm{cm}$ 破裂強度：13.4 kg/cm² で鼠高檤を示した。木線混用の 場合はポリエステル浘用についで，その值が高く，羊毛 混用の笏合は，抗張力: $0.27 \mathrm{~kg} / \mathrm{mm}^{2}$, 伸び: $30 \%$, 引 裂強度: $7.6 \mathrm{~kg} / \mathrm{cm}$, 破烈強度: $7.6 \mathrm{~kg} / \mathrm{cm}^{2}$ で最低の值 を示した。クロム コラーダン䋊維を主体とした不織布 虫緹横の引治強度 $1: 1$, 抗張力 $0.75: 1$, 伸び 0.93 : 1となり性とんど万向性がなく不織布として好察しい性 質を具供している。

\section{$4 \cdot 4$}

クロム コラーゲン紻維は可紡性を持っている。しか し䋐維条件で 100\%のるのはカーデング性にややこしい が、フェルト化の項で述べたように他種臓維と琨紡すれ

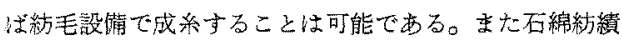
設備に上れば混紀率 $10 \%$ 以下でる強力口支る系とする ことはできる。これらの紡績糸を製布すればクロムコ ラーダン䋐維の特筫である吸放湿性を活かした建材瀻維 品中車輛内貼布汇利用される。

\section{5 クロム・コラーゲン䄉維の電気植毛加工への 利用 ${ }^{12\rangle}$}

クロム・コラーゲン䋐維を通常の皮革染色と同様, 主と して酸性染料で染色加工しウエップに成型，それを0.2 $\sim 2.0 \mathrm{~mm}$ 程度所定の長さ比切断する。クロム コラー ゲン微小絩維恃相互に粘着しやすい状態にあるので, ア セトン、アルコールなどにより溶剂分散したのち䈱別し

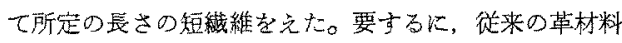

電気植毛品はシェービング㻺，パッフイング频を破砩し たものを使用していたが，それらは粒状のため接着度は 良くなかった。クロムコラーゲン䋐維の電着植毛品は

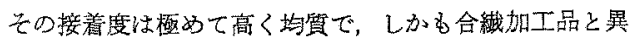
なったいかゆるしが味のある電着植毛品とすることがで きる

\section{5. ま め}

クロム林草よりクロム・コラーダン瀻維の回取方法损 よびクロム ニラーゲン溨維の性質と利用方法の概要を 記述したがしかし，開発されて日我浅く今後の研究にま だねば，その性質括よび利用方法も溝足すべすので ない。

先学各位のご指導老期待するるのでる。

文献

1) 特許公告 No. 14426, 昭和 37 年 9 月

2）特許公告 No. 17069，昭和 38 年 9 月

3）特許公告 No. 1550 , 昭和 12 年

4) 岡村浩; 皮革技術, 10, No. 1，88 (1965)

5）岡村 浩，太団搏文 5; 皮龩化学，11，No. 2, 100 (1965)

6）岡村 浩，太田博文方; 皮革化学, 11，No. 4, 199 (1966)

7) 岡村浩，太田博文后; 埼丙皮革研究全誈，No. 27,91 (1966)

8）阔村 浩; 日畜会報，32, No. 2，99 (1961)

9）岡村浩; 日畜会報，32，№.6，35（1961）

10）闻村洁，菅野英二郎; 仅革化学，13，No. $2 ， 61$ (1967)

11）阙村浩，太田博文与; 埼玉皮革研究会誈，No， 27,96 (1966)

12）岡村浩，太田博文与; 埼玉皮草研究会誌，No. $27,100(1966)$

13）岡村浩，太男博交; 皮英化学，12，№４， 213 (1967)

(昭和 42 年 9 月 26 日受理) 